\title{
QUALITY OF FINANCIAL CONGLOMERATES' PERFORMANCE IN EMERGING ECONOMY: THE INDUSTRIAL ORGANIZATION THEORY PERSPECTIVE
}

\author{
Wiwiek Rabiatul Adawiyah ${ }^{1}$, Bambang Agus Pramuka ${ }^{2}$ \\ ${ }^{1}$ Department of Management Faculty of Economics and Business \\ ${ }^{2}$ Department of Accounting Faculty of Economics and Business \\ University of Jenderal Soedirman \\ HR Bunyamin 709 Purwokerto, 53122, Indonesia
}

\begin{abstract}
Keywords: conglomeration, internal capital market, resource sharing, managerial ownership

JEL Classification: D23, E22, G32

Financial conglomerates are financial institutions that provide all forms of financial services on the top of ordinary banking service. The quality of financial conglomerates' performance depends on number of factors namely ownership structure, internal capital market and resources sharing. Research on the performance of financial conglomerates are still lacking in Indonesia. This study, therefore, is among the first attempt to assess the influence of ownership structure, internal capital market and resources sharing on the performance financial conglomerate firms in Indonesia, from the industrial organizational theory perspectives. The methodology employed is the ex-post facto research design, using secondary data. The population of the study is all the conglomerates firms listed on the Indonesian Stock Exchange between 2010 until 2015 persistently. The study used regression as a tool of analysis. Findings supported three out of the five hypotheses proposed. Efficient subsidy and managerial ownership had no significant influence on firms' performance. Efficient transfer segment had positive influence on firms' performance. Similarly, result supported the proposition that intangible and tangible resources had positive effect on firms' performance.
\end{abstract}

\section{ABSTRAK}

Konglomerat keuangan adalah lembaga keuangan yang memberikan segala bentuk layanan keuangan di samping layanan perbankan pada umumnya. Kualitas kinerja konglomerat keuangan dipengaruhi oleh berbagai faktor antara lain struktur kepemilikan modal, pasar modal internal dan berbagi sumberdaya. Penelitian tentang konglomerat keuangan di Indonesia masih sangat terbatas, khususnya yang berfokus pada kinerja perusahaan dari perspektifteori organisasi industri. Oleh karena itu penelitian ini merupakan salah satu upaya awal untuk mengkaji pengaruh struktur kepemilikan modal, pasar modal internal dan berbagi sumberdaya terhadap kinerja keuangan perusahaan konglomerasi keuangan di Indonesia dari perspektif teori organisasi industri. Penelitian ini menggunakan pendekatan kuantitatif, dengan desain ex-post facto, menggunakan data sekunder. Populasi penelitian adalah semua perusahaan konglomerat yang terdaftar di Bursa Efek Indonesia selama tahun 2010 sampai dengan 2015. Metode analisis yang digunakan adalah regresi berganda. Hasil penelitian ini mendukung tiga dari lima hipotesis yang diajukan. Subsidi yang efisien dan kepemilikan manajerial tidak berpengaruh terhadap kinerja perusahan konglomerat keuangan di Indonesia. Sementara itu segmen transfer efisien, sumberdaya berwujud dan tidak berwujud berpengaruh positif terhadap kinerja perusahaan konglomerat keuangan. 
There is a strong view in the literatures that performance can determine the sustainability and existence of firms in the market as it influence the decision of continues patronage by investors, potential investors, creditors, and other stakeholders in the business world (Andow \& David, 2016). Every firm should demonstrate ability to make returns in this highly competitive environment as it determines its ability to survive in the future. Conglomeration emerges because of companies' effort to diversify their business in huge scale aiming at minimizing risk and maximizing profit. Diversification enables firms to access the efficient global capital markets (Schoen, 2008). A conglomerate company is a market-diversified firm, which means that it operates in two or more markets (Narver, 1967).

A number of publications on conglomeration are evidences in finance literature with considerable disagreement on the benefits of merging firms in different businesses' lines (Berger et al., 1999). The conglomeration hypothesis' advocates assert that possessing and wielding different kind of businesses lines under one roof shall provide advantages in the form of cost efficiency by sharing inputs in joint production (Mälkönen, 2009). Conglomeration leads to financial efficiency and capital gain by initiating internal capital markets, which may be more resistance to market imperfections, such as information asymmetries, compared to external markets to imperfections (Gertner et al., 1994). Internal capital market is the main motive for firms in conducting diversification as it works on the basis of cross subsidization whereby profitable segment subsidizes the unprofitable one and low growth potential segment subsidizes the high potential one (Huang et al., 2012). This mechanism shall reduce the risk faced by firms in the market. Conglomerations provide benefits to firms in many forms: reduce risk (Boot \& Schmeits, 2000; Tremblay \&Trembley, 2012), improve firms' financial leverage, providing greater revenues from risk-sensitive customers who are willing to pay more or accept reduced services in return for lower default risk (Winton 1999), and increase market power (Bashir \& Fedorova, 2014)

Researches on the implications of financial conglomeration in emerging economies are still lacking (Mälkönen, 2009). Among attempted works were: Mälkönen (2009) and Morrison (2003) address the issue of risks and regulatory aspects associated with financial conglomerates; Boot \& Schmeits (2000) concluded that conglomeration shall alleviate risk-taking in banking, however, creates moral hazard problems between the divisionsof a financial group. Financial conglomerates are having financial advantage (Freixas et al., 2007) and information advantage (Vander, 2002) over specialized firms.

Existing literature omit the industrial organization aspects of financial conglomeration and ignores the empirical fact that financial conglomerates emerge as a result of synergies, such as lockin effects and cost efficiency gains (Mälkönen, 2009). For instance, Freixas et al. (2007) and Boot \& Schmeits (2000) assume perfectly competitive markets where the products and the customers of the conglomerates are identical. Efficiency motives occurs as a result of synergy gains such as economies of scale and scope or reduced transaction costs (Golubov et al., 2013) and earn profit from diversification of different product lines (Mälkönen, 2009). Thus, the diversification opportunity is a plausible reason for the emergence of financial conglomerates. Information obtained from other financial services provides advantages to financial institutions (Mester et al., 2007) thus providing better access for the conglomerates to global capital markets (Schoen, 2008). Some other advantages of conglomerate mergers are in the form of managerial motives such as diversification and reduced risks (Tremblay \& Trembley, 2012). In addition, conglomerate mergers aim at 


\section{Jurnal Keuangan dan Perbankan | KEUANGAN}

Vol. 21, No. 2, April 2017: 176-187

increasing market power by eliminating potential competitors in the market (Tremblay \& Trembley, 2012).

Financial conglomeration syndrome in Indonesia is ubiquitous, evidences by its increasing numbers. According to the Financial Service Authority (FSA) report in 2015, financial conglomerates control 69.5 percent, or equivalent with 5.325 trillion Rupiah, of the financial service industry' total asset. Most financial conglomerates in Indonesia are experiencing managerial ownership participation. Nonetheless, researches on the performance of those firms are still limited. Performance is crucial to every business's survival that reflects continues patronage by investors, potential investors, creditors, and other stakeholders in making investment decision. The companies' ability to get higher return shall determine to a larger extend its ability to survive in the future. The influences on the firm value by managerial ownership and foreign ownership have been issues that researchers have undertaken to investigate for decades (Andow \& David, 2016). This study provides additional evidence regarding the way in which ownership structure, internal capital market and resources sharing influence the conglomerate firms' performance in Indonesia focusing on the conflict emanating on incentives due to managerial ownership participation on corporate governance structure and their impact on the firm's performance.

Moreover, conglomeration provides benefits in the form of internal capital market and resource sharing. Sautner \& Villalonga (2010) stated that internal capital market rose because of poor corporate governance. They argue that ownership structure focus will decrease the extent of diversified firm therefore having more efficient internal capital market. This result support the work of Kim \& Jung (2003) who suggested that funds allocation within firms where controlling shareholders have high ownership are more efficient com- pared to those shareholders with low ownership holding.

Despite of the facts that internal capital market is the main motivation for company doing diversification, research on internal capital markets is yet inconclusive. Some supported the view that internal capital market resulted in conglomerate firm's efficiency (Gertner et al., 2001; Billet \& Mauer, 2003; Campello, 2005; Schoen, 2008; Huang et al., 2012; and Almeida \& Kim, 2014). In the meantime, others urged that internal capital market performed inefficiently make decreasing firm value (Ozbas \& Scharfstein, 2010; Billet et al., 2013). The blame for conglomerates' inefficiency was on the way they allocate resources across industries. Investment by segment of highly diversified firms is less sensitive to their cash flow. Ozbas \& Scharfstein (2010) alleged that the unrelated segments of conglomerate firms tend to invest less than stand-alone firms in high-Q industries, and more than stand-alone firms in low-Q industries. Internal capital market in this inquiry is classified into efficient subsidy segment and efficient transfer segment. Thus, the following hypothesis is proposed:

$\mathrm{H}_{1}$ : efficient subsidy segment has positive influence on the performance of conglomerate firms.

$\mathrm{H}_{2}$ : efficient transfer segment has positive influence on the performance of conglomerate firms.

Another benefit of conglomeration is resources sharing. According to Resource-Based View theory, resources are the ultimate driver for a firm to establish its identity and framing its strategy. Therefore, firms' resources become the primary sources of the firm's profitability (Grant, 2001). Both intangible and tangible resources are the critical source of competitive advantage and performance. Intangible resource, such as adver- 
tising, leads a firm to diversified entry and performance in many different markets without changing the business nature (Chatterjee \& Wernelfelt, 1991). Meanwhile, tangible resource, such as funds, is the most flexible type of all resource because they can be used to acquire all sorts of productive resources (Chatterjee \& Wernelfelt, 1991). Financial resources are among important sources of competitive advantage and economic growth in Korea (Change \& Hong, 2002). It helps increase scale and scope economies, vast knowledge and experiences in diversified businesses (Park et al., 2008)

Resources are means to create competitive advantages in the market (Barney, 1991). A series of studies have attempted to link strategic resources and performance. Some scholars concluded that there is no effective connection between resources and performance (Coff \& Lee, 2003). Instead, strategic resources explain performance only to the extent that organizations capture the economic value that they create (Barney \& Clark, 2007). Resources is the primary reason for the firm to establish its identity and frame its strategy, hence become the primary sources of the firm's profitability.Thus, the following hypothesis are proposed:

$\mathrm{H}_{3}$ : intangible resources have positive influence on the performance of conglomerate firms.

$\mathrm{H}_{4}$ : tangible resources have positive influence on the performance of conglomerate firms.

Research on the relationship between managerial ownership and corporate performance are widely discovered in developed countries and more recently in emerging markets (Andow \& David, 2016). Ownership structure is a pivotal issue for corporate governance and hence firms' performance (Andow \& David, 2016). Separation of ownership and control motivates management to reduce incentives in order to maximize corpo- rate efficiency. Therefore, right proportion of ownership and control in required in minimizing conflict of interest.The agency theory can be used as a reference to clarify the role of ownership structure in mitigating this conflict of interest. On the one hand, a firm with larger spread of ownership may be advantageous in terms of lower risk of owner-manager conflict. On the other hand, owner with the largest proportion of ownership may exercises their power to gain private benefits while compensating those with smaller portion of ownership (Bashir \& Fedorova, 2014). Thus the following hypothesis is proposed:

$\mathrm{H}_{5}$ : managerial ownership has negative influence on the performance of conglomerate firms.

The framework of this study is based on the theory of industrial organization. The theory explains the relationship between the organizational structure an industry and the economic behavior of a company in terms of transaction costs, barriers to entry, monopoly and conglomeration (Bashir \& Fedorova, 2014). This theory also explains the characteristics of an industry such as market structure, conduct and performance of the organization's industry. Industrial organization theory is based on the paradigm of structure-conductperformance (Cabral, 2000). The theory suggests that conglomeration is one of the core elements of an industry's market structure. Horizontal concentration is the most crucial factors as it derives to larger extend market's structure (Li \& Chen, 2007). It implies that firms is similar or same business category are more likely to merge (Bashir \& Fedorova, 2014). The theory of industrial organization explains about conglomeration and their rolein market competition. Wirth \& Bloch (2009) alleged that conglomeration is a condition whereby large economic conglomerates capable of outspending market competitors through cross-subsidization own market competitors. In the case of 


\section{Jurnal Keuangan dan Perbankan | KEUANGAN}

Vol. 21, No. 2, April 2017: 176- 187

conglomeration, a company expands by acquiring other firms in related or unrelated fields. Figure 1 presents the framework of the study.

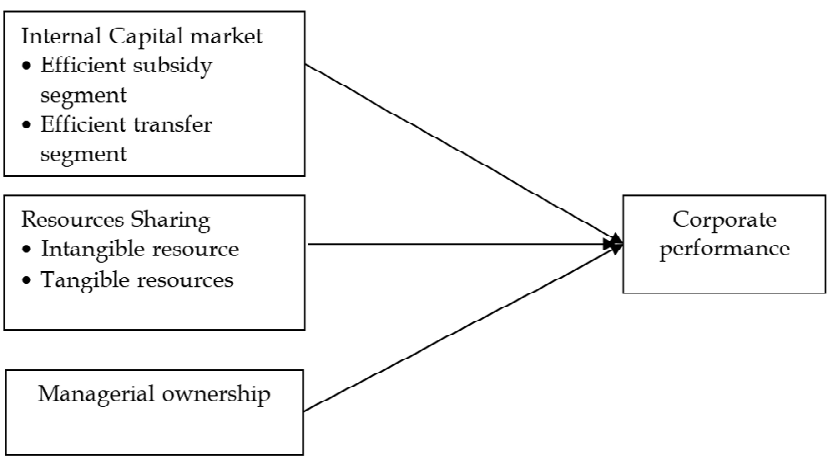

Figure 1. Research framework

\section{METHOD}

The sample of the study was financial conglomerate firms listed in the Indonesia Stock Exchange. The sampling method adopted was purposive sampling with certain criteria namely: top 49 conglomerate companies according to the Financial Service Authority and the company actively published their financial statements since 2010 until 2015 consecutively. The observations was conducted for five years which is slightly longer than the study period used in some previous studies. Longer observation coverage provides advantages in terms of better understanding on the variable under study.

The variable of the study consists of firm's performance as dependent variables measured by Tobin's $Q$ ratio. The formula of Tobin's $Q$ is calculated using the approximate $Q$ by Chung \& Pruitt (1994) as follows:

$\mathrm{Q}=\frac{\mathrm{MVE}+\mathrm{PS}+\mathrm{Debt}}{\mathrm{TA}}$

Where,

MVE : the product of firm's share price and the number of common stock shares outstanding
PS : liquidating value of the firm's outstanding preferred stock

Debt : the value of the firm's short-term liabilities net of its short-term assets, plus the book value of the firm's long-term debt

TA : the book value the total asset of the firm

The independent variables in this study consist of internal capital market, resources sharing and ownership structure. Internal capital market is classified two components namely subsidy and transfer (Billet \& Mauer, 2003). While subsidy receiver is a segment lacking of fund, the transfer segment is the opposite. Subsidy occurs when after-tax cash flow ('ATCF') is less or equal to capital expenditures ('CAPEX') while transfer segment is vice versa. The following formula is used to measure subsidy and transfer (Billet \& Mauer, 2003).

Firm Subsidy $_{i}=\operatorname{Max}\left(\mathrm{CAPX}_{\mathrm{i}}-\mathrm{ATCF}_{\mathrm{i}^{\prime}} 0\right)$

Firm Subsidy $_{\mathrm{i}}=\operatorname{Max}\left\{\mathrm{CAPX}_{\mathrm{i}}-\left(\mathrm{EBIT}_{\mathrm{ij}}-\right.\right.$ interest $_{\mathrm{ij}}-$ $\operatorname{tax}_{\mathrm{ij}}+$ depreciation $\left.\left._{\mathrm{ij}}\right), 0\right\}$

where,

CAPEX $_{i}$ : the segment's reported capital expenditures

ATCF $_{i} \quad:$ the segment's after-tax cash flow, including

EBIT $_{\mathrm{ij}} \quad$ : segment i's reported earnings before interest and tax

Interest $_{\mathrm{ij}} \quad$ : interest expense i's segment

$\operatorname{Tax}_{\mathrm{ij}} \quad:$ tax expense i's segment

Depreciation $_{\mathrm{ij}}$ : depreciation expense i's segment

The potential transfer of resources of the transfer segments ('PTransfer') is calculated using the following formula:

Transfer $=\min \left\{\frac{\text { PTransfer } \mathrm{i}}{\sum_{\mathrm{i}=1}^{\mathrm{n}} \text { PTransfer } \mathrm{i}}\left(\sum_{\mathrm{i}=1}^{\mathrm{n}}\right.\right.$ Subsidy $\left.\mathrm{i}\right)$, PTransfer $\left._{\mathrm{i}}\right\}$ 
PTransfer $_{i}=\max \left(\mathrm{ATCF}_{\mathrm{i}}-\mathrm{w}_{\mathrm{i}} \mathrm{DIV}_{\mathrm{j}}-\mathrm{CAPEX}_{\mathrm{i}^{\prime}} 0\right)$

Where,

PTransfer : potential transfer segment $\mathrm{i}$

DIV $_{j} \quad$ : cash dividend paid by firm $j$

$\mathrm{w}_{\mathrm{i}} \quad$ : asset weighted of the total number of transfer segments i, i.e., those segments for which ATCF $\geq$ CAPEX.After deduction of dividends, PTransfer can be positive or 0 .

To measure the efficiency of the internal capital market components for an nsegment will use ROA as computed as

$\mathrm{ESS}=\sum \frac{\left(\mathrm{ROA}_{\mathrm{i}}-\overline{\mathrm{ROA}}\right)\left(\text { Subsidy }_{i}\right)\left(\text { Positive }_{i}\right)}{\text { Total Asset }}$

ETS $=\sum \frac{\left(\overline{\text { ROA }}-\text { ROA }_{I}\right)\left(\text { Transfer }_{i}\right)\left(1-\text { Positive }_{i}\right)}{\text { Total Asset }}$

Where the define following indicator variables for segmenti:

Positive $=\left\{\begin{array}{l}1 \text { if ROA }_{i}>\overline{\mathrm{ROA}} \\ 0 \text { if ROA }_{i} \leq \overline{\mathrm{ROA}}\end{array}\right.$

The next variable is resource, which is defined as anything could be thought of as a strength or weakness of a given firm (Wernerfelt, 1984). Firm's resources could be defined as intangible and tangible resources. The proxy of advertising as intangible resources and liquidity as tangible resources are presented below:

Advertising $=\frac{\text { Advertising Expenditure }}{\text { Total Sales }}$

Liquidity $=\frac{\text { Current Assets }}{\text { Current Liabilities }}$

The last independent variable is ownership structure. This variable is measured using the per- centage of managerial ownership within financial conglomerate companies. The formula is as follows:

Ownership Structure $=\frac{\text { Managerial Ownership }}{\text { Total Ownership }}$

The method of analysis used is panel data regression model as suggested by Gujarati (2013). Regression equation model in this study used fixed effects least square dummy variable (LSDV) model.The result of Chow test indicated that $\mathrm{F}$ test value $(0,00)$ which was below 0.05 . The data was analyzed using statistical software Eviews 9.

$$
\begin{aligned}
Q_{i t}= & \beta_{1 \mathrm{i}}+\beta_{2} \operatorname{Sub}_{\mathrm{it}}+\beta_{3} \operatorname{Trn}_{\mathrm{it}}+\beta_{4} \mathrm{Adv}_{\mathrm{it}}+\beta_{5} \mathrm{Liq}_{\mathrm{it}} \\
& +\beta_{5} \mathrm{Os}_{\mathrm{it}}+\mathrm{u}_{\mathrm{it}}
\end{aligned}
$$

\section{RESULTS}

Classical assumption tests were undertaken prior to conducting the regression analysis. Normality distribution is the simple comparison distribution and only involve two parameters, mean and varians (Gujarati, 2013). Jarque-Bera (JB) is in Eviews statistical test to determine whether the data was normally distributed. The Jarque-Bera value of 0.595188 is less than $x^{2}$ of 37.65 while the probability value of 0.742603 is greater than 0.05 , thus the data is considered normal and can be processed for further analysis.

Partial correlation within independent variable is used to test multicollinearity. If correlation coefficient $(\mathrm{r})<0.8$, it means that there is no multicollinearity. The result of the analysis is presented in Table 1.

The result of analysis indicated that all significant values are above 0.05 confirming the absence of heteroscedasticity. The result of autocorrelation test is 2.081764 while the value of $\mathrm{dL}$ is 1.0706 and $\mathrm{dU}$ is 1.8326 , indicating no autocorrelation. 
Table 1. Correlation Matrix

\begin{tabular}{lccccc}
\hline & ESS & ETS & ADV & LIQ & OS \\
\hline ESS & 1.000000 & -0.495397 & -0.116289 & 0.119926 & -0.171159 \\
ETS & -0.495397 & 1.000000 & 0.037147 & -0.070246 & 0.253223 \\
ADV & -0.116289 & 0.037147 & 1.000000 & -0.359847 & -0.418278 \\
LIQ & 0.119926 & -0.070246 & -0.359847 & 1.000000 & 0.619990 \\
OS & -0.171159 & 0.253223 & -0.418278 & 0.619990 & 1.000000 \\
\hline
\end{tabular}

Table 2. Result of Fixed Effects Least Square Dummy Variable (LSDV) Model

\begin{tabular}{lrrrc}
\hline \multicolumn{1}{c}{ Variable } & Coefficient & Std. Error & t-Statistic & Prob. \\
\hline ESS & -93.09696 & 46.41728 & -2.005653 & 0.0586 \\
ETS & 0.009157 & 0.004220 & 2.169781 & 0.0422 \\
ADV & 6.031876 & 1.820771 & 3.312814 & 0.0035 \\
LIQ & 0.963517 & 0.324494 & 2.969290 & 0.0076 \\
OS & -0.032102 & 0.032239 & -0.995747 & 0.3313 \\
C & -0.697585 & 0.346181 & -2.015088 & 0.0575 \\
\hline
\end{tabular}

Table 3. Adjusted R Square

\begin{tabular}{llll}
\hline \multicolumn{3}{c}{ Effects Specification } & \\
\hline Cross-section fixed (dummy variables) & & \\
R-squared & 0.983516 & F-statistic & 132.5893 \\
Adjusted R-squared & 0.976098 & Prob (F-statistic) & 0.000000 \\
\hline
\end{tabular}

Where:

$$
\begin{array}{ll}
\mathrm{i} \quad: \text { unit cross section (financial institution) } \\
\mathrm{t} \quad: \text { unit time series (year) } \\
\mathrm{u} \quad: \text { residual value } \\
\text { ESS } \quad \text { : efficient subsidy segment } \\
\text { ETS : efficient transfer segment } \\
\text { ADV : advertising expenditure } \\
\text { LIQ : liquidity } \\
\text { OS : Ownership structure }
\end{array}
$$$$
\begin{aligned}
\mathrm{Q}_{\text {it }}= & -0.697585-93.09696 \mathrm{ESS}_{\text {it }}+0.009157 \mathrm{ETS}_{\text {it }}+ \\
& 6.031876 \mathrm{ADV}_{\text {it }}+0.963517 \mathrm{LIQ}_{\text {it }}-0.032192 \mathrm{OS}_{\text {it }}+\mathrm{u}_{\text {it }}
\end{aligned}
$$

Regression analysis was used to test the partial influence of independent variable on dependent variable (Gujarati, 2013). From the analysis using alpha $=0.05$ and a degree of freedom $(n-k)$, it is known that the value of $t$ table is 1.708 . The analysis result indicated that all significant values are less than 0.05 except for efficient subsidy seg- ment and ownership structure. The proxy for intangible resource is advertising. Based on the partial influence, the test result shows that $t_{\text {stat }}$ was 3.312814 and $t_{\text {table }}$ was 1.708 with the significant value 0.0035 . The coefficient of advertising was positive and have significant coefficient. Thus, the third hypothesis which states that there is a positive effect intangible resource to Tobin's $Q$ in the financial conglomerate listed on the Indonesia Stock Exchange, support hypothesis. Financial resource is one of tangible resource form. The proxy for tangible resource is liquidity. The result showed that $t_{\text {stat }}$ was 2.969290 and $t_{\text {table }}$ was 1.706 with the significant value 0.0076 . The coefficient of liquidity was positive and have significant coefficient. Thus, the fourth hypothesis which states that there is a positive effect tangible resource to Tobin's $Q$ in the financial conglomerate listed on the Indonesia Stock Exchange support hypothesis. 
Based on the partial influence test on the effect of managerial ownership, it appeared that $\mathrm{t}_{\text {stat }}$ was -0.032102 and $\mathrm{t}_{\text {table }}$ was 1.706 with the significant value 0.3313 . The coefficient of managerial ownership was negative and have no significant coefficient. Thus, the fourth hypothesis that states that there is a negative effect managerial ownership to Tobin's $Q$ in the financial

To assess the simultaneous effect of the model, F test was employed with the confidence level of $95 \%$. It is indicated in the study that the sig value was less than 0.05 or $\mathrm{F}_{\text {statistic }}$ was 132.5893 greater than $\mathrm{F}_{\text {table }}$ of 2.69. Thus, it is resumed that efficient subsidy segment, efficient transfer segment, advertising, liquidity, and ownership structure affect financial conglomerate performance.

In addition, Table 3 show the coefficient determination $\left(R^{2}\right)$ and adjusted $R^{2}$ of the model were 0.983516 and 0.976098 consecutively. It indicates that $98.3 \%$ of the variation in the rise and fall of the conglomerate performance can be explained by efficient subsidy segment, efficient transfer segment, advertising, liquidity, and ownership structure while $1.7 \%$ is explained by other variables not observed in the study. The value of adjusted $\mathrm{R}^{2}$ of 0.976098 indicating that $97.6 \%$ of variation in firms' performance can be explained by efficient subsidy segment, efficient transfer segment, advertising, liquidity, andownership structure while the remaining of $2.4 \%$ is explained by other variables not included in the model.

\section{DISCUSSION}

The first hypothesis stating that efficient subsidy segment has positive effect on performance of conglomerate firm listed on the Indonesia Stock Exchange was not supported. The finding of this study is distinct from the work of Billet \& Mauer (2003) and Huang et al. (2012). They found that internal capital market identified through subsidy has significantly positive effect on conglomerate firms. This research examined internal capital market through the subsidy constructed for the unconstrained segment among subsidiaries of a financial conglomerate company. The result revealed that efficient subsidies have no positive effect on Tobin's $Q$ and the market does not use internal information in doing investment appraisal. The explanation in line with the argument of Billet \& Mauer (2003). They argue that one advantage of internal capital market is the emergence of conglomerate companies' ability to provide fund some prospective investment opportunities of segments that would have been financially constrained provided they were stand-alone firms. This allegation is consistent with the efficient internal capital market theory, which predicts that only efficient cross-subsidization to financial constrained segment experience increasing in value. In addition, Shin \& Stulz (1998) found that the cross-subsidization and the capital allocation tend to be inefficient in diversified firms. The evidence shows that significantly the own cash flow is more useful for the segment investment than cash flow of the firm other segment. Clearly, forms of organization matter in performances of the firm (Brickley et al., 2007).

The second hypothesis stated efficient transfer segment has positive effect on performance of conglomerate firm listed on the Indonesia Stock Exchange support the hypothesis. The result of the research is similar with with Stein (1997) and Khanna \& Tice (2001) who argued that internal transfer creates value for conglomerates. The results of this study support the " winner-picking " style theory where a manager who has more information about the company, will work better in the selection of projects. Furthermore, the manager shall put the capital of the segment that produces the investment opportunities, are limited to other segments that can create a more favorable value. Internal capital market theory said that the transfer of efficient, that is the transfer of segments 


\section{Jurnal Keuangan dan Perbankan | KEUANGAN}

Vol. 21, No. 2, April 2017: 176-187

with unfavorable investment opportunity should have a positive effect on firm performance (Billet \& Mauer, 2003). Large organizations tend to be more bureaucratic and management costs rise (Park et al., 2008). Itis appropriate with internal capital market theory and the result suggest that a higher transfer of segment with poor investment opportunity increase the segment with good investment opportunity.

Intangible resource is everything of immaterial existence used or potentially usable for whatever purpose that is renewable after use and decreases, remains or increases in quantity and/or quality while being used (Diefenbach, 2006). The study supported the third hypothesis which states that there is a positive effect intangible resource to Tobin's Q in the financial conglomerate listed on the Indonesia Stock Exchange. Villalonga (2004) states that intangible assets play an important role in sustaining a firm's competitive advantage, as predicted by the resource-based view of the firm. They also suggest that intangible assets play nearly as important role in sustaining a firm's competitive disadvantage. Similarly, Hirschey \& Weygandt (1985) found that advertising has positive effect on the market value of the firm. Change \& Hong (2002), which examined intangible resource through advertising of other firms in the same business group, have a positive and significant impact on the profitability of group-affiliated firm. Hsua \& Jang (2008), Sahay \& Pillay (2009) also found that advertising expenditure has a significant positive effect on the value of the firm mea- sured using Tobin's Q. Politics also play a role in conglomerate organizations, and can result in inefficient resource allocation when bureaucratic organization loses timely decision making and adaptation to changing environments (Park et al., 2008).

Tangible assets are the easiest 'resources' to identify and are often found on a firm's balance sheet that include production facilities, raw materials, financial resources, real estate, and computers (Diefenbach, 2006). The study also supported the fourth hypothesis that states that there is a positive effect tangible resource to Tobin's $Q$ in the financial conglomerate listed on the Indonesia Stock Exchange. Similarly, Change \& Hong (2002) examined financial resource through liquidity found that liquidity has positive effect on firm performance. The research result means that a higher level of liquid capital at the group level leads to higher firm performance. The significant result show that the market using information about company liquidity in doing investment appraisal. Companies possessing large portion of current asset have greater to opportunity to transfer their cash into other assets' forms at any time (Prihantini, 2009). The high liquidity willattract the investors to invest their fund in the company so that the company performance also will get more. From the result above, both of variable highlight the model fit with the theory that the resources is the firm strength to implement the strategy and create the competitive advantages to get performance advantages.

Table 3. Result Summary

\begin{tabular}{lccc}
\hline \multicolumn{1}{c}{ Hypothesis } & Significant Value & Final Result \\
\hline Efficient Subsidy Segment $+\mathrm{Y}$ & $\longrightarrow$ & 0.0586 & Not supported \\
Efficient Transfer Segment $+\mathrm{Y}$ & $\longrightarrow$ & 0.0422 & Supported \\
Intangible Resource $+\mathrm{Y}$ & $\longrightarrow$ & 0.0035 & Supported \\
Financial Resource $+\mathrm{Y}$ & $\longrightarrow$ & 0.0076 & Supported \\
Managerial Ownership $-\mathrm{Y}$ & $\longrightarrow$ & 0.3313 & Not supported \\
\hline
\end{tabular}


The study revealed that the fourth hypothesis which states that there is a negative effect managerial ownership to Tobin's $Q$ in the financial conglomerate listed on the Indonesia Stock Exchange not to support hypothesis. The result of the research is different from Bashir \& Fedorova (2014) owner with the largest proportion of ownership may exercises their power to gain private benefits while compensating those with smaller portion of ownership.

\section{CONCLUSION AND SUGGESTION}

\section{Conclusion}

The result of the study revealed that the first hypothesis stating that efficient subsidy has significant influence on firms' performance was not supported. Similarly the fifth hypothesis states that managerial ownership has negative influence on firms' performance. The study supported the second hypothesis stating that efficient transfer segment has positive influence on firms' performance. Likewise the inquiry result supported the third hypothesis stating that intangible resources has positive effect on firms' performance. The, fourth hypothesis, tangible resources has positive influence on firms' performance was also supported.

This research has some implication, as follows: for management, if a company faces financial constrained, internal capital market can be more efficient than external capital market. Managers can place their investment into variety of segments in order to create a more favorable value within group. Internal capital market provides easy way to manage capital that later increase the companies' performance. However, when the internal capital market is inefficient, managements face the problem of rising agency cost. Based on the findings, both resources variable has a positive and significant effect on performance. Therefore, management should maintain and improve the resource in order to increase the firms' value.

\section{Suggestion}

This research have some limitations. First, the sample of the study was financial conglomerate company listed on Indonesia Stock Exchange. To increase generalizability of the result it is advisable to enlarge the sample to other conglomerate firms across different sectors. Second, the observed periods were limited to 6 years. Future research could extend the period of study in order to minimize bias. Future model may use different measure of subsidy and transfer efficiency, for example fitted $Q$ and enhance the observations across regions. The result of the study provide guideline for managers in order to act in the best interest of the company while solving financial constraint. When firms efficient, the performance of the conglomerate firms shall increase. This study also enhance literature in the field of financial conglomerations. As the phenomena is ubiquitous in Indonesia lately, the number of publication in the area are still limited especially in terms of market efficiency.

\section{REFERENCES}

Andow, H.A., \& David, B.M. 2016, Ownership Structure and the Financial Performance of Listed Conglomerate Firms in Nigeria. The Business and Management Review, 7(3): 231-240

Almeida, H., Kim, B., \& Kim, C.S. 2014. Internal Capital Markets in Business Groups: Evidence from the Asian Financial Crisis. Journal of Finance, 70(6): 2539-2586. DOI: 10.1111/jofi.12309

Barney, J.B. 1991. Firm Resources and Sustained Competitive Advantage. Journal of Management, 17: 99120.

Barney, J.B., \& Clark, D.N. 2007. Resource-Based Theory: Creating and Sustaining Competitive Advantage, New York: Oxford University Press Inc.

Bashir, M., \& Fedorova, M. 2014. Conglomeration among the Top American Public Relations Agencies: A Case Study. Public Relations Review, 40(5), 762-771. https://doi.org/ 10.1016/j.pubrev.2014.10.005 


\section{Jurnal Keuangan dan Perbankan | KEUANGAN}

Vol. 21, No. 2, April 2017: 176-187

Berger, P.G., \& Ofek, E. 1995. Diversification's Effect on Firm Value. Journal of Financial Economics, 37: 3965.

Billet, M.T., \& Mauer, D.C. 2003.Cross-Subsidies, External Financing Constraints, and the Contribution of the Internal Capital Market to Firm Value. Review of Financial Studies, 16(4): 1167-1201. DOI:https://doi.org/10.1093/rfs/hhg024

Brickley, J.A., Clifford S. Jr. \& Jerold Z. 2007. Managerial Economics and Organizational Architecture. New York: Mc.Graw Hill/Irwin, 304-477.

Boot, A.W.A., \& Schmeits, A. 2000. Market Discipline and Incentive Problems in Conglomerate Firms with Applications to Banking. Journal of Financial Intermediary, 9(3): 240-273.

Cabral, L. 2000. Introduction to Industrial Organization. Cambridge: MIT Press.

Campello, M. 2002. Internal Capital Markets in Financial Conglomerates: Evidence from Small Bank Responses to Monetary Policy. Journal of Finance, 57(6): 2773-2805.

Change, S., \& Hong, J. 2002. How Much Does the Business Group Matter in Korea? Strategic Management Journal, 23: 265-274.

Chatterjee, S., \& Wernerfelt, B. 1991. The Link between Resources and Type of Diversification: Theory and Evidence. Strategic Management Journal, 12(1): 3348.

Chung, K.H., \& Pruitt, S.W. 1994. A Simple Approximation of Tobin's Q, Financial Management, 23(3): 7077

Coff, R., \& Lee, P. 2003. Insider Trading as A Vehicle to Appropriate Rent from R\&D. Strategic Management Journal, 24(2): 183-90.

Diefenbach, T. 2006. Intangible Resources - A Categorial System of Knowledge and Other Intangible Asset. Journal of Intellectual Capital, 7(3): 406-420.

Freixas, X., Lóránth, G., \& Morrison, A.D. 2007. Regulating Financial Conglomerates. Journal of Financial Intermediary, 16(4): 479-624.

Gertner, R.H., Scharfstein, D.S. \& Stein, J.C. 1994. Internal versus External Capital Markets. The Quarterly Journal of Economics, 109: 1211-123.
Golubov, A., Petmezas, D., \&Travlos, N. 2013. Empirical Mergers and Acquisitions Research: A Review of Methods, Evidence and Managerial Implications. In A. Bell, C. Brooks, \& M. Prokopczuk (Eds.). Handbook of Research Methods and Applications in Empirical Finance. Northampton: Edward Elgar Publishing.

Grant, R.M. 1991. The Resource-Based Theory of Competitive Advantage: Implications for Strategy Formulation. CaliforniaManagement Review, 33(3): 114135. Available at SSRN: https://ssrn.com/abstract $=1504481$

Gujarati, D. 2013. Ekonometrika Dasar. Alih bahasa oleh Sumamo Zain.Jakarta: Erlangga.

Hirschey, M. \& Weygandt, J.J. 1985. Amortisation Policy for Advertising and Research and Development Expenditures. Journal of Accounting Research, 23(1), 326-35.

Hsua, L.T., \& Jang, S.C. 2008, Advertising Expenditure, Intangible Value and Risk: A Study of Restaurant Companies. International Journal of Hospitality Management, 27: 259-267

Huang, Y., Tang, J., \& Zhou, X. 2012. The Efficiency of Internal Capital Markets: Evidence From Conglomerate Firms Around Financial Crisis. Paper Presented in the 10th China International Conference in Finance (CICF 2012), Chongqing, China,

Khanna, N., \& Tice, S. 2001. The Bright Side of Internal Capital Markets.Journal of Finance, 56(4).

Kim, B., \& Jung, K. 2003. Internal Fund Allocation and Ownership Structure: Evidence from Korean Business Group. Review of Quantitative Finance and Accounting, 25(1): 33-53. doi:10.1007/s11156-0053178-7.

Li, S., \& Chen, Y. 2007. Market Competition and Media Performance: Reexamining the Media Performance of the Cable Television Industry in Taiwan. Journal of Media Economics, 20(3): 189-210. Retrieved from http://dx.doi.org/10.1080/01292989909359622

Mälkönen, V. 2009. Financial Conglomeration and Monitoring Incentives. Journal of Financial Stability, 5: 105-123.

Mester, L.J., Nakamura, L.I., \& Renault M., 2007. Transactions Accounts and Loan Monitoring. Review of Financial Studies, 20: 529-556. 


\section{Quality of Financial Conglomerates' Performance in Emerging Economy: The Industrial Organization Theory Perspective}

Wiwiek Rabiatul Adawiyah \& Bambang Agus Pramuka

Morrison, A.D., 2003. The Economics of Capital Regulation in Financial Conglomerates. The Geneva Paper on Risk Insurance, 28(3): 521-533.

Narver, J. 1967, Conglomerate Mergers and Market Competition. Los Angeles: University of California Press.

Ozbas, O., \& Scharfstein, D.S. 2010. Evidence on the Dark Side of Internal Capital Markets. The Review of Financial Studies, 23(2): 581-599. doi:10.1093/rfs/ hhp071

Park, H.Y., Shin, G., \& Suh, S.H. 2008. Advantages and Shortcomings of Korean Chaebols, International Business \& Economics Research Journal, 7(1): 57-66.

Prihantini, R. 2009. Analisis Pengaruh Inflasi, Nilai Tukar, ROA, DER dan CR terhadap Return Saham (Studi Kasus Saham Industri Real Estate and Property yang Terdaftar di Bursa Efek Indonesia Periode 2003-2006. Tesis. Program Magister Manajemen Pascasarjana Universitas Diponegoro. Semarang.

Sahay, A., \& Pillai, A. 2009. Differential Impact of Advertising and Distribution Expenditure on Tobin's Q: A Perspective from Listed Firms in India. Journal of Indian Business Research, 1(2/3): 77-94.

Sautner, Z., \& Villalonga, B. 2010. Corporate Governance and Internal Capital Markets, Working Paper. Harvard Business School.
Schoen, D. 2008. Internal Capital Markets in Diversified Firms; Does It Enhance Firm Value? Thesis. Bachelor Business Economics Specialization Finance University of Amsterdam. Amsterdam.

Shin, H., \& Stulz, R.M. 1998. Are Internal Capital Markets Efficient? Quarterly Journal of Economics, 113: 531-552.

Tremblay, V., \& Trembley, C. 2012. New Perspectives on Industrial Organization. Springer Texts in Business and Economics, http://dx.doi.org/10.1007/9781-4614-3241-81

Vander, V.R. 2002. Cost and Profit Efficiency of Financial Conglomerates and Universal Banks. European Journal of Money Credit Bank, 34(1): 254-282.

Villalonga, B. 2004. Intangible Resources, Tobin's Q, and Sustainability of Performance Differences. Journal of Economic Behavior EOrganization, 54: 205-230.

Winton, A. 1999. Don't Put All Your Eggs in One Basket? Diversification and Specialization in Lending. Working Paper. Finance Department, University of Minnesota, Minneapolis.http://www.businessdictionary.com/ definition/financialresources.html\#ixzz4 0JTRIWl. Accessed 16 February 2016.

Wirth, M.O. \& Bloch, H. 2009. Industrial Organization Theory and Media Industry Analysis. Journal of Media Economics, 8(2): 15-26. http://dx.doi.org/ $10.1207 / \mathrm{s} 15327736 \mathrm{me} 0802$. 